Pengabdian Kepada Masyarakat

\title{
Edukasi dalam Pencegahan Covid-19 Dusun Cabean melalui Pemberdayaan Masyarakat
}

\section{Tri Nurhidayati ${ }^{1}$, Muchayan Haryadi², Latifah Khoirun Nisak ${ }^{1}$, Arief Yanto ${ }^{1}$}

1 Fakultas Ilmu Keperawatan dan Kesehatan, Universitas Muhammadiyah Semarang, Indonesia

2 Fakultas Teknik, Universitas Muhammadiyah Semarang, Indonesia

\section{Informasi Artikel}

\section{Riwayat Artikel:}

- Submit 13 Mei 2021

- Diterima 8 Juni 2021

- Diterbitkan 10 Juni 2021

Kata kunci:

Covid-19; Upaya preventif;

Empowerment

\begin{abstract}
Abstrak
Pencegahan Covid-19 sangat penting dilakukan pada saat pandemic. Pengabdian masyarakat dengan sasaran program ibu-ibu, anak-anak, serta masyarakat di lingkungan tempat tinggal mahasiswa. Penulis merancang beberapa program khusus yang berkaitan dengan COVID-19, dengan pertimbangan untuk tetap mematuhi protokol kesehatan yang berlaku. Program-program yang telah penulis rancang diharapkan dapat tercapainya tujuan dari tema yang telah di pilih. Tujuan program-program antara lain. 1) mengetahui kesadaran masyarakat dan anak-anak terhadap bahaya covid19 , 2) menambah wawasan kepada masyarakat tentang gejala dan pencegahahan Covid-19, 3) menanamkan kebiasaan mematuhi protokol kesehatan dan pola hidup bersih. Metode pelaksanaan menggunakan langkah sebagai berikut: identifikasi potensi dan menganalisis permasalahan di masyarakat, perancangan program, penelitian pustaka untuk acuan materi yang digunakan selama pengabdian, metode observasi lapangan untuk mengetahui lokasi penambahan tempat cuci tangan dan mendatangi masyarakat secara langsung. Berdasarkan observasi lapangan terdapat perbedaan yang mengarah pada hal yang lebih baik mengenai kesadaran masyarakat terhadap bahaya Covid-19, ketika sebelum dan sesudah pelaksanaan.
\end{abstract}

\section{PENDAHULUAN}

Infeksi virus yang marak saat ini yaitu virus covid-19, virus ini pertama kali ditemukan di kota Wuhan, Cina, pada akhir Desember tahun 2019 belakangan ini. Severe acute respiratory coronavirus 2atau biasanya disingkat dengan (SARS-Cov-2) lebih dikenal dengan nama virus corona adalah jenis virus baru dari corona virus yang menular ke manusia. Virus Corona biasanya bisa ditemukan pada manusia dan hewan. Sebagian dari virus dapat menginfeksi manusia serta menyebabkan berbagai penyakit lainnya diantaranya seperti : flu, hingga penyakit-penyakit fatal lainnya. Virus ini juga bisa menyerang siapa saja dari bayi, anak-anak, orang dewasa, lansia, ibu hamil, maupun ibu menyusui (Citrawati et al., 2020) . Gejala - gejala dari virus ini juga berbagai macam sesuai dari tingkat keparahan dari virus itu sendiri ada pasien yang terjangkit tetapi tidak timbul gejala (asimtomatik), terdapat gejala -gejala awal dari (demam, batuk kering, pilek, nyeri kepala, nyeri tenggorokan, mual, dll), tahap

Corresponding author:

Tri Nurhidayati

tnh@unimus.ac.id

SALUTA: Jurnal Pengabdian Kepada Masyarakat, Vol 1 No 1, Juni 2021

DOI: https://doi.org/10.26714/sjpkm.v1i1.8556 
selanjutnya yakni masuk pada tahap pneumonia (terjadi sesak nafas, hipoksemia, CPR meningkat, dan dapat ditemukan pnemunia terhadap pemeriksaan radiologi yang dilakukan), selanjutnya akan terjadi tahap yang lebih parah lagi seperti penyakit ARDS, badai sitokin,sepsis, miokarditis hingga terjadi kematian (Otálora, 2020).

Kasus positif Covid-19 di Indonesia pertama kali pada awal bulan Maret 2020. Penyebaran virus Corona (Covid-19) di Indonesia masih cukup tinggi sampai saat ini. . Jumlah kasus per 10 Maret 2021 mencapai 1.398 .578 orang, sementara pasien sembuh sebanyak 5.556 orang dan total pasien meninggal akibat pandemi virus Corona di Indonesia mencapai 37.932 orang (Rachmadi, 2021). Menjaga jarak,mengurangi kerumunan dan membiasakan diri dengan pola hidup sehat merupakan salah satu cara paling efeketif untuk mencegah penularan Covid-19. Mengedukasi masyarakat tentang pencegahan Covid-19 juga sangatlah penting tetapi dengan mematuhi protokol kesehatan yang ada. Dengan adanya edukasi pencegahan Covid-19 diharapkan masyarakat bisa mendapatkan informasi yang benar dan menjalankan protokol kesehatan dengan penuh kesadaran.

Tujuan diadakannya Pengabdian masyarakat ini adalah sesuai tema "Edukasi Pencegahan Covid-19”. Program kerja Kami adalah memberikan informasi yang benar kepada masyarakat tentang pencegahan Covid-19,pemberian vitamin, masker dan handsanitizer alami serta penyediaan tempat cuci tangan dan kebersihan tempat ibadah.

Warga Dusun Cabean sendiri masih terbilang banyak yang tidak mematuhi protokol kesehatan dalam aktivitas sehari- hari. Seperti tidak memakai masker saat keluar rumah, tidak menjaga jarak, maka Pendidikan kesehatan yang kami lakukan ini adalah kegiatan untuk menyampaikan pesan, menanamkan keyakinan, sehingga masyarakat tidak saja sadar, tahu dan mengerti, tetapi juga mau dan bisa melakukan suatu anjuran yang ada hubungannya dengan kesehatan Masyarakat memiliki peran penting dalam kesuksesan kegiatan ini , diharapkan masyarakat juga bisa mengaplikasikan tentang apa yang telah disampaikandalam kegiatan ini. Diharapkan dengan adanya edukasi pencegahan Covid-19 ini masyarakat mau dan lebih melindungi diri dengan cara mematuhi protokol kesehatan yang telah dianjurkan oleh pemerintah. Serta hal ini diharapkan dapat mencegah penyebaran Covid 19 ini yang semakin lama semakin bertambah jumlah yang terkena dampak virus ini (Purnamasari \& Ell Raharyani, 2020).

\section{METODE}

Metode pelaksanaan yang kami gunakan mengikuti langkah identifikasi sebagai berikut: identifikasi potensi dan menganalisis permasalahan didalam masyarakat, perancangan program, penelitian pustaka untuk acuan materi yang digunakan selama pengabdian, metode observasi lapangan dilakukan untuk mengetahui lokasi dan tempat yang perlu diberi ember dan sabun cuci tangan, serta menanamkan kebiasaan mencuci tangan dan memakai masker (Firdausi et al., 2020). 
Rincian Program, dan kegiatan mahasiswa yang terlibat tersaji dalam Tabel 1, Tabel Metode Pengabdian.

Tabel 1

Tabel Metode Pengabdian

\begin{tabular}{|c|l|l|}
\hline No. & \multicolumn{1}{|c|}{ Metode } & \multicolumn{1}{|c|}{ Kegiatan } \\
\hline 1 & Identifikasi potensi & Diskusi \\
\hline 2 & Perancangan program & $\begin{array}{l}\text { Eiskusi } \\
\text { covid }\end{array}$ \\
\hline 3 & Observasi lapangan & $\begin{array}{l}\text { Pembagian vitamin, masker dan handsanitizer } \\
\text { herbal }\end{array}$ \\
\hline 4 & $\begin{array}{l}\text { Observasi lapangan dengan membagikan } \\
\text { masker,vitamin dan handsanitizer herbal }\end{array}$ & $\begin{array}{l}\text { Penyediaan ember dan sabun cuci tangan } \\
\text { lokasi yang perlu ditambahkan ember cuci dan sabun } \\
\text { untuk cuci tangan. }\end{array}$ \\
\hline 6 & $\begin{array}{l}\text { Observasi lapangan membersihkan masjid seperti } \\
\text { menyapu, mengepel serta mencuci mukena masjid } \\
\text { yang digunakan bergantian. }\end{array}$ & Perawatan tempat ibadah \\
\hline 7 & $\begin{array}{l}\text { Observasi lapangan dengan bersih-bersih lingkungan } \\
\text { masjid sekaligus penyemprotan cairan desinfektan }\end{array}$ & $\begin{array}{l}\text { Kebersihan lingkungan dan penyemprotan } \\
\text { cairan desinfektan }\end{array}$ \\
\hline
\end{tabular}

\section{HASIL DAN PEMBAHASAN}

Pelaksanaan seluruh program dilakukan secara langsung sesuai himbauan protokol kesehatan dari rumah ke rumah sehingga tidak menciptakan kerumunan.Program pertama adalah edukasi mengenai gejala dan pencegahan Covid-19

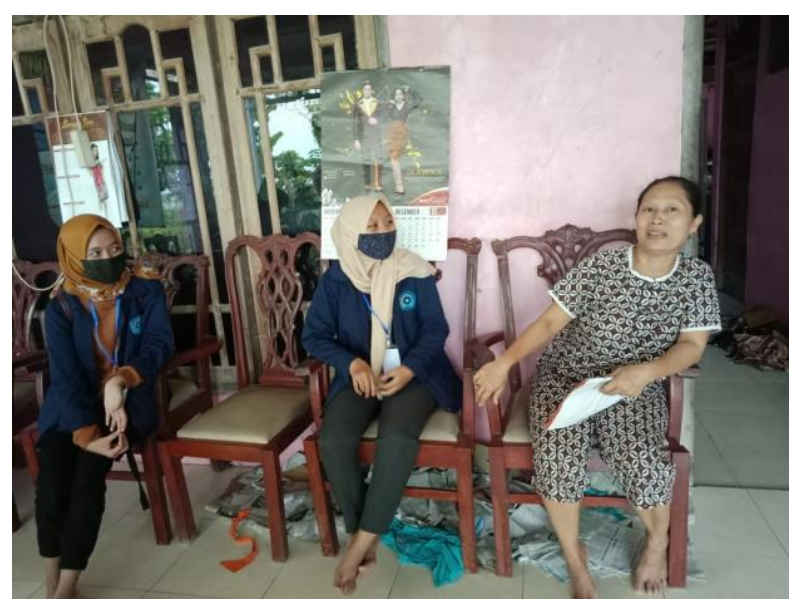

Gambar 1

Tim Mendatangi Warga (Dokumentasi Pribadi, 2021)

Gambar 1 menunjukkan kegiatan ketika mendatangi beberapa rumah warga untuk menginformasikan tentang gejala dan pencegahan Covid-19. Media yang digunakan dengan leaflet(Jaji, 2020). Kegiatan ini kami lakukan saat pagi hari hingga siang hari. Sebagian warga sudah memahami tentang gejala dan pencegahan Covid-19, Namun terdapat juga yang masih belum mengetahui secara rinci informasi tersebut.

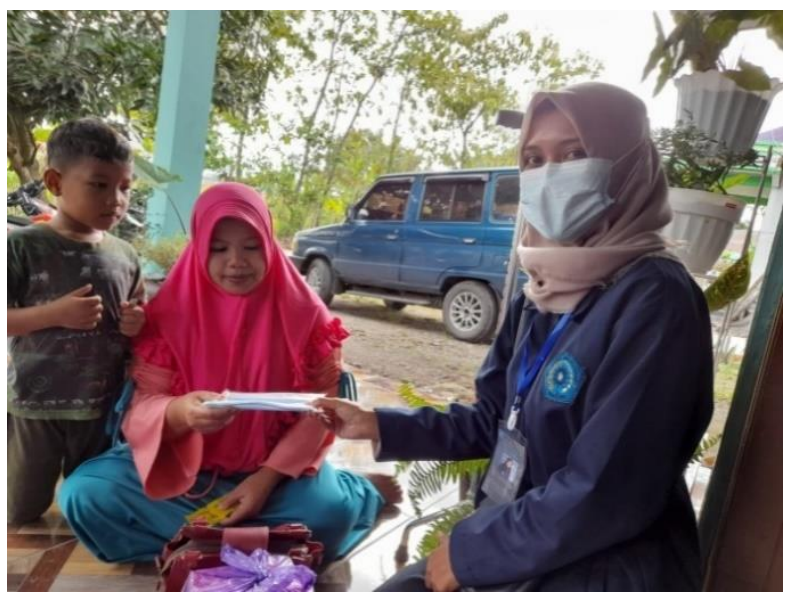

Gambar 2

Pembagian Masker Kepada Warga (Dokumentasi Pribadi, 2021)

Gambar 2 yakni pembagian masker kepada warga Serta memberikan informasi tentang penularan Virus Corona. 


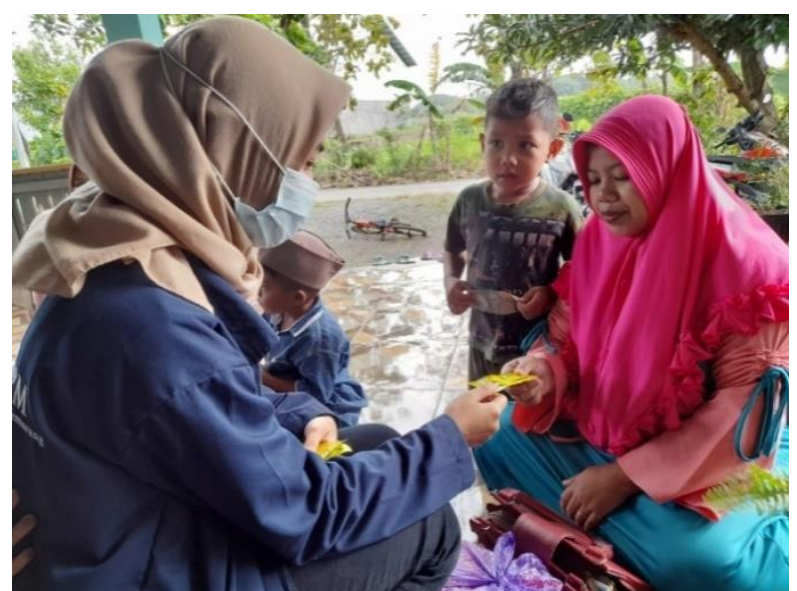

Gambar 3

Pembagian Vitamin Kepada Ibu-ibu dan Anak-anak (Dokumentasi Pribadi, 2021)

Gambar 3 yakni Pembagian vitamin kepada warga terutama Ibu-ibu dan anak-anak untuk menunjang imun tubuh saat beraktifitas di masa pandemi ini.

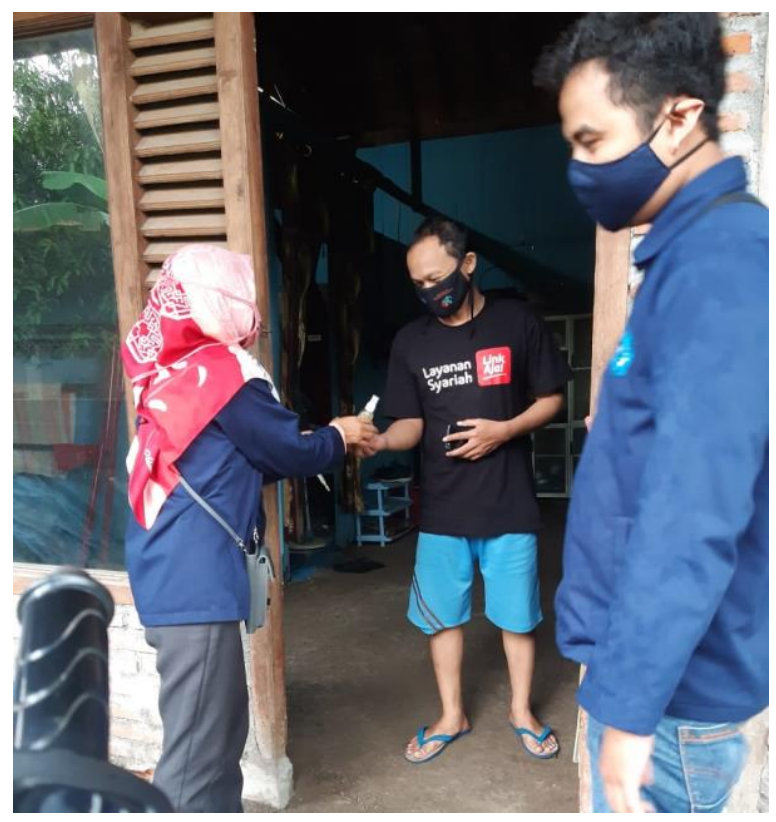

Gambar 4

Pembagian Handsanitizer Alami ke Rumah Warga

(Dokumentasi Pribadi, 2021)

Gambar 4 merupakan kegiatan pembagian handsanitizer alami kepada warga dari rumah-kerumah sebanyak 20 botol. Kegiatan ini kami lakukan dari siang sampai sore hari, sekaligus memberikan informasi mengenai manfaat dari daun sirih dan jeruk nipis sebagai antiseptik alami pengganti alkohol.

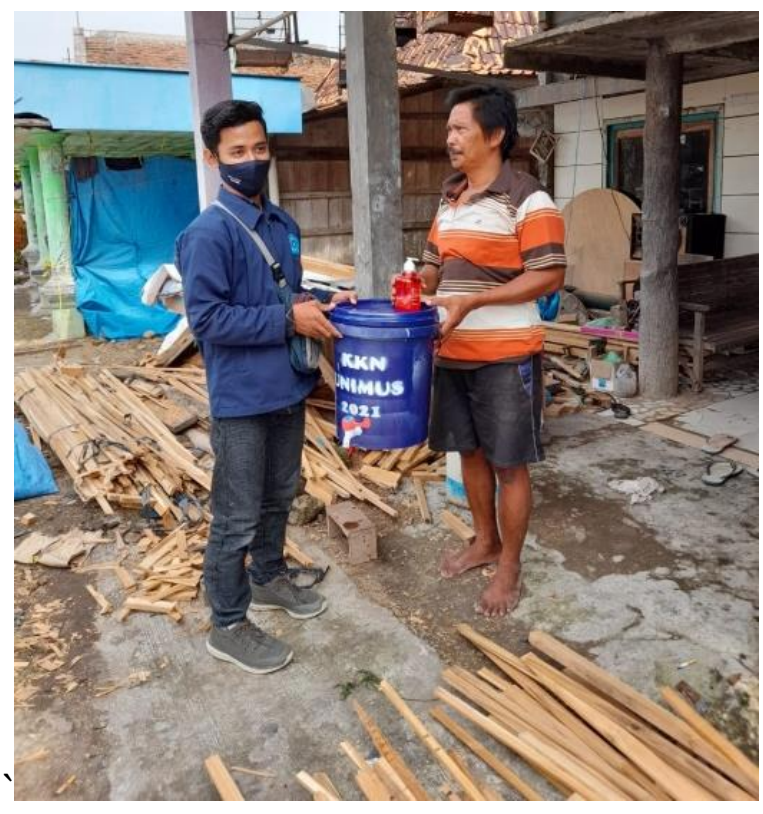

Gambar 5

Kegiatan Pembagian Ember dan sabun cuci tangan (Dokumentasi Pribadi, 2021)

Gambar 5 merupakan kegiatan pembagian ember dan sabun cuci tangan ke beberapa rumah warga yang belum punya tempat cuci tangan . Kegiatan ini diharapkan dapat membantu warga yang masih kesulitan menyediakan tempat cuci tangan. Kegiatan cuci tangan sangat penting untuk warga , sebagai salah satu bentuk pencegahan covid 19 (Syakurah \& Moudy, 2020).

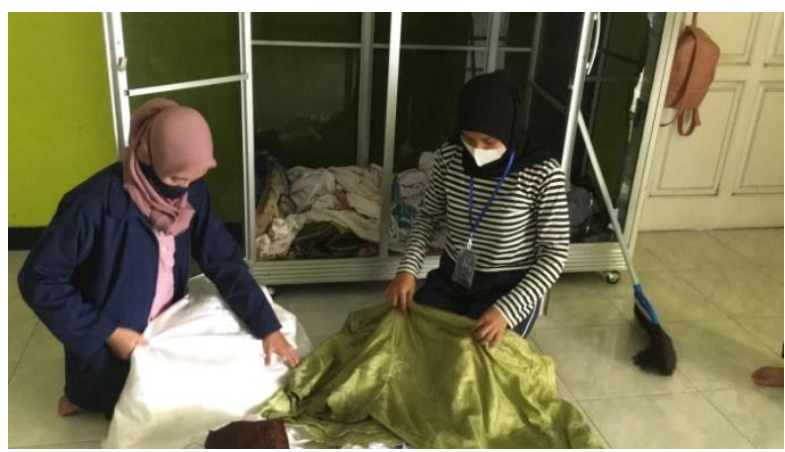

Gambar 6

Kegiatan Bersih-Bersih Masjid (Dokumentasi Pribadi, 2021)

Gambar 6 adalah kegiatan bersih-bersih masjid yamg menjadi tempat berkumpulnya warga ketika melakukan 
sholat 5 waktu maupun sholat jum'at. Seperti menyapu mengepel dan mencuci mukena masjid.

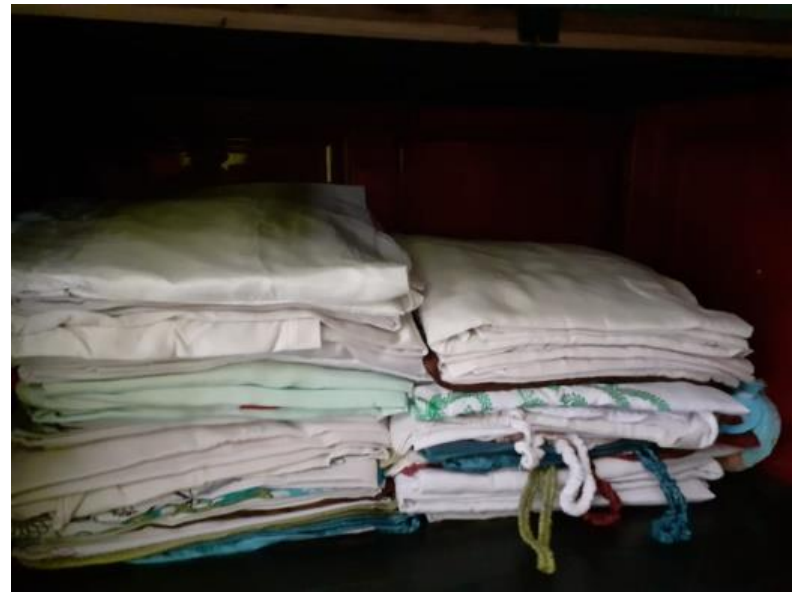

Gambar 7

Mukena Masjid yang Sudah di Rapikan

(Dokumentasi Pribadi, 2021)

Gambar 7 adalah Tampilan mukena yang sudah selesai dicuci dan dijemur kemudian dilipat dan disimpan kembali ke dalam lemari masjid.

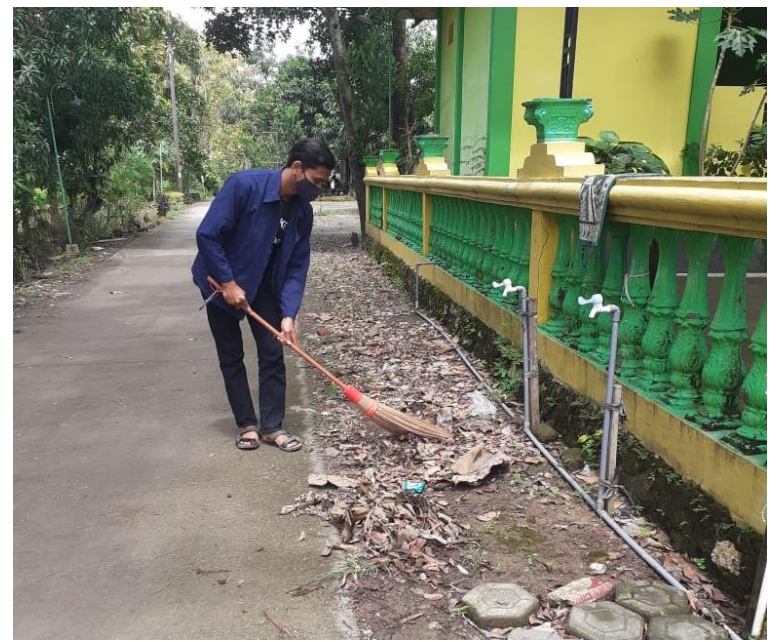

Gambar 8

Kegiatan bersih-bersih lingkungan (Dokumentasi Pribadi, 2021)

Gambar 8 menunjukan kegiatan bersihbersih di lingkungan sekitar masjid, membersihkan daun-daun yang berjatuhan serta membersihkan rumput dan sampah plastik yang sudah menumpuk.

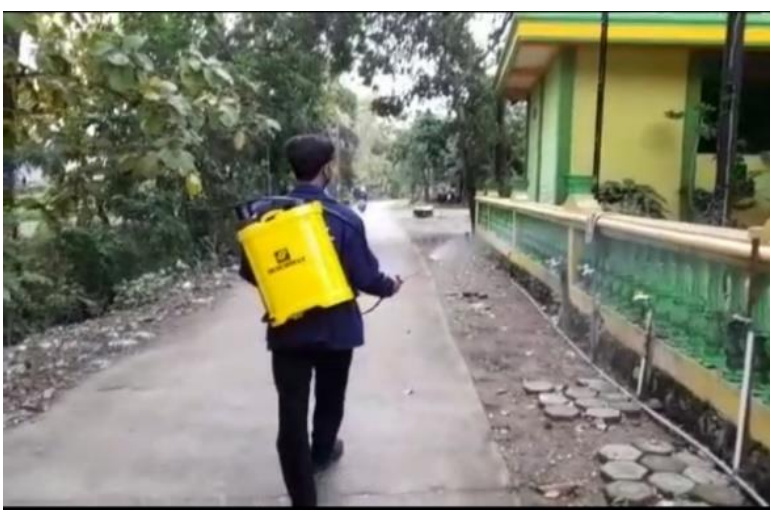

Gambar 9

Kegiatan Penyemprotan Desinfektan (Dokumentasi Pribadi, 2021)

$\begin{array}{lcr}\text { Gambar } 9 & \text { merupakan } & \begin{array}{r}\text { kegiatan } \\ \text { penyemprotan }\end{array} \\ \text { cairan } & \text { desinfektan } \\ \text { dilingkungan sekitar masjid. } & \end{array}$

Pada program pertama yakni edukasi gejala dan pencegahan Covid-19. Setelah kami berkeliling dan berkunjung ke rumahrumah warga. Sebagian besar warga sudah memahami mengenai pencegahan Covid-19 tetapi ada juga yang paham mengenai gejala tertularnya virus Covid-19. Oleh karena itu, dengan adanya program ini dapat meningkatkan dan menambah wawasan masyarakat sekitar mengenai gejala dan pencegahan Covid-19.

Pada program kedua yakni Pembagian Masker, Vitamin dan Handsanitizer Alami, Penggunaan masker, pemberian vitamin, dan handsanitizer merupakan upaya pencegahan covid yang penting(Alsan et al., 2021)Sebagai upaya kami untuk menunjang aktifitas warga sehari-hari agar terhindar dari penyebaran virus Corona. Kami dapati masih banyak warga yang belum mematuhi protokol kesehatan. Kegiatan ini berjalan dengan lancar dan mendapat respon yang baik, sehingga penyampaian informasi tentang penularan Covid-19 dapat diterima dengan baik oleh warga.

Pada program ketiga yakni pembagian ember dan sabun cuci tangan, kegiatan ini dapat mempermudah masyarakat dalam menyediakan tempat cuci tangan dan cara 
hidup bersih sesuai anjuran dari pemerintah (Yanti et al., 2020).

Pada program ke empat yakni perawatan tempat ibadah, menjaga kebersihkan masjid menjadi upaya kami dalam mencegah penularan Covid-19. Masjid ini mempunyai lokasi diseberang jalan raya, setiap harinya banyak orang dari luar daerah yang singgah untuk beristirhat dan melaksanakan sholat.. Untuk itu penting untuk selalu menjaga kebersihan tempat ibadah. Kebutuhan spiritual diperlukan sebagai upaya pemenuhan kebutuhan selama pandemi(Demartoto et al., 2020).

Pada program kelima yakni Kebersihan lingkungan dan penyemprotan desinfektan, Kegiatan ini dimulai dari memebersihkan sampah daun dan plastik yang menumpuk di sekitara masjid. Kemudian dilanjut dengan penyemprotan cairan dsinfektan dari pagar hingga pintu dan ruangan masjid. Kegiatan ini kami lakukan dari pagi hingga siang hari.

Keseluruhan program yang sudah kami laksanakan di dukung oleh masyarakat sekitar. Kegiatan-kegiatan berlangsung lancar dan sangat antusias.

\section{SIMPULAN}

Kegiatan sosialisasi mendapat sambutan yang positif dri masyarakat, dimana mereka sangat membutuhkan informasi yang jelas dan benar tentang Covid-19. Tindakan pencegahan terhadap Covid-19 mulai diterapkan oleh masyarakat setelah pelaksanaan kegiatan. Masyarakat sadar akan penerapan kebiasaan hidup sehat seperti menjaga kebersihan, rajin mencuci tangan dengan sabun dan air bersih, memakai masker, menyediakan handsanitizer dan desinfektan dirumah serta tempat-tempat umum, menjaga jarak dan mengurangi aktivitas diluar rumah sebagai upaya pemutusan rantai penyebaran Covid-19.
Penulis menyadari sepenuhnya jika artikel ini masih banyak kesalahan dan jauh dari sempurna. Oleh karena itu, untuk memperbaiki artikel tersebut penulis meminta kritik yang membangun dari pembaca.

\section{UCAPAN TERIMA KASIH}

Penulis mengucapkan terimakasih kepada semua pihak yang telah membantu dalam persiapan dan pelaksanaan pengabdian kepada masyarakat ini.

\section{REFERENSI}

Alsan, M., Stanford, F. C., Banerjee, A., Breza, E., Chandrasekhar, A. G., Eichmeyer, S., GoldsmithPinkham, P., Ogbu-Nwobodo, L., Olken, B. A., Torres, C., Sankar, A., Vautrey, P. L., \& Duflo, E. (2021). Comparison of Knowledge and Information-Seeking Behavior After General COVID-19 Public Health Messages and Messages Tailored for Black and Latinx Communities : A Randomized Controlled Trial. Annals of Internal Medicine, 174(4), 484-492. https://doi.org/10.7326/M20-6141

Citrawati, N. K., Sukraandini, N. K., Mirayanti, N. K., \& Ketut, S. A. (2020). Tingkatkan Pengetahuan dan Kesadaran Masyarakat Dalam Memutus Rantai Penularan Virus Covid -19 Di Wilayah Desa Tumbu Karangasem. 3(2), 147-150.

Demartoto, A., Sunesti, Y., Haryono, B., \& Mundayat, A. A. (2020). Life Story of Patient With Supervision'S Fighting Against Covid-19 in Surakarta Indonesia. Jurnal Analisa Sosiologi, 9(2), 423-435. https://doi.org/10.20961/jas.v9i2.44436

Firdausi, U., Candra, L. F. K., \& Karma, C. P. F. (2020). Pengabdian Masyarakat Dan Anak-Anak Melalui Kkn-T Mengenai Edukasi Pencegahan Covid-19 Di Desa Dukuh Cikupa. ABDIPRAJA (Jurnal Pengabdian Kepada Masyarakat), 1(1), 14-23.

Jaji. (2020). Pengaruh pendidikan kesehatan dengan media leafletterhadap pengetahuan warga dalam pencegahan penularan covid 19. Proceeding Seminar Nasional Keperawatan 2020, 1, 135-139.

Otálora, M. M. C. (2020). Yuliana. Parque de Los Afectos. Jóvenes Que Cuentan, 2(February), 124-137.

https://doi.org/10.2307/j.ctvzxxb18.12 
SALUTA: Jurnal Pengabdian Kepada Masyarakat, Vol 1 No 1, Juni 2021/ page 7-13

Tri Nurhidayati - Edukasi dalam Pencegahan Covid-19 Dusun Cabean melalui Pemberdayaan Masyarakat

Purnamasari, I., \& Ell Raharyani, A. (2020). Tingkat Pengetahuan Dan Perilaku Masyarakat Kabupaten Wonosobo Tentang Covid -19. Living Islam: Journal of Islamic Discourses, 3(1), 125.

Syakurah, R. A., \& Moudy, J. (2020). Pengetahuan terkait usaha pencegahan Coronavirus Disease (COVID-19) di Indonesia. HIGEIA (Journal of Public Health Research and Development), 4(3),
333-346.

Yanti, N. P. E. D., Nugraha, I. M. A. D. P., Wisnawa, G. A., Agustina, N. P. D., \& Diantari, N. P. A. (2020). Gambaran Pengetahuan Masyarakat Tentang Covid-19 Dan Perilaku Masyarakat Di Masa Pandemi Covid-19. Jurnal Keperawatan Jiwa, $8(4), 491$. 